\title{
A Game Theory Analysis on Local Governments' Competition for New Energy Industries
}

\author{
Xiaoming Qiu \\ Department of Economics and Management \\ University of Electronic Science and Technology of \\ China,Zhongshan Institute, \\ Zhongshan, China \\ bayes510@163.com
}

\author{
Ying Wang \\ School of Management and Economics, \\ University of Electronic Science and Technology of \\ China , \\ Chengdu, China \\ 513695847@qq.com
}

\begin{abstract}
This paper analyzes the ongoing game scenario of local governments' efforts in developing new energy industries under a tournament-type performance appraisal system and draws two conclusions on the basis of chicken game and firstprice sealed auction. The two conclusions are: (1) local governments' competition efforts present a likelihood of excess capacity in the new energy sector instead of the intended overall promotion of the industries, thus reducing the local profits and harming the long-term sector-wide benefits; (2) the competing game between new-energy investors and local governments assumes a high degree of possibility of landing local governments in a prisoners' dilemma, thus alluring local governments to adopt any preferential policy options in fear of losing the game.
\end{abstract}

Keywords-local governments; new energy industries; performance assessment mechanism; game theory; chicken game

\section{PREFACE}

At the Copenhagen climate change conference of 2009, Chinese Premier Wen Jiabao announced the Chinese government target of cutting carbon dioxide emissions per unit of GDP by $40-45 \%$ from the 2005 level by 2020 . This target is incorporated into the strategic planning of China's economic development.

Encouraged by their respective ambitious climate targets, local governments at all levels demonstrated unprecedented interest in new energy industries in a bid to accomplish the compulsory strategic promise. Statistics have shown that over a half of all provinces in China are setting up new energy industry zones or taking the industry as an additional engine for their economic growth, and over 100 municipalities are making plans to develop new energies. Jiangsu Province is a typical example. Among the 13 prefecture-level cities in Jiangsu, 10 are setting up those industrial parks related to the emerging sector. The province also came up with the China's first local program for the newly-sought-for industry: sales volumes are expected to be 180 billion yuan for 2009, 300 billion yuan for 2010, and 450 billion for 2011, in a striking contrast to 90 billion yuan in 2008. Shanghai and Zhejiang just followed the suit.

Intense competition triggered by this industrial priority forced various localities (provinces and municipalities) to stage large numbers of investment projects in the clean energy sector. For example, China now owns about 50 polycrystalline silicon producers while that number of worldwide producers is as small as about eight. And China now has about 300 solar cell businesses while there are about eight in the whole world. Also, China now boasts about 80 air blower manufacturers, with a large number of entrants each month. In addition, to be winners in the competition, local governments are strongly stimulated to provide subsidies for the emerging energy sector. In Shenzhen, government-provided subsidies for each new energy vehicle buyer amount to as high as 500,000-600,000 yuan. Guangzhou rolled out the same subsidizing policies for new-energy transportation vehicles and private cars. This scenario of intense competition and fiscal subsidies is inherently associated with and substantially strengthened by industrial recruitment efforts and GDP growth impetus by local governments at all levels.

Admittedly, any infant industry enjoys a high degree of dependence on the visible hand. However, the ongoing situation of competition and subsidizing in the new energy sector in China is too much impacted by the government role. With the government's pushing hand and GDPoriented performance system, the new energy industry is endangered with irrationality which is bound to bring about industrial bubbles and artificially translate the loss-making programs into profit-making ones. Why the craving for the new energy sector? Why the cutthroat competition in the sector? These are the questions this paper tries to answer. By expounding and analyzing the formative mechanism of this new energy game-playing by the local governments, this paper aims at showing the impact brought about by the game results on the emerging industry in China. The analysis will be done on two levels: game analysis on the industrial policy options between local governments and on the industrial alliance between local governments and new energy investors.

\section{LITERATURE REVIEW}

Overseas literature on government competition focuses mainly on fiscal competition. David scones (2001) created a simple tax competition model to research how common and region-specific competition impacts the tax abatement efforts by local governments in terms of project value. The research indicated that competition lowered the equilibrium 
tax rates and that the relative magnitude of project value is the key factor for measuring competition-induced tax reductions and corporate profit increases. Kangoh Lee (2003) explained, by citing case studies, how the stable factors in equilibrium fiscal policies impact the ownership structure, arguing that tax rates changes caused by tax competition are contingent on the stable factors in fiscal policies, and that individual ownership of land in other regions will impact the boundary Nash equilibrium of local governments. Sergio (2005), basing his work on measuring methods and case studies, offered an empirical discussion on the differentiated taxation on production factors and on the necessity of interjurisdictional strategic interdependence, made an analysis on the objectives and instruments of intergovernmental fiscal competition, and proposed a policy framework for fiscal competition. Michael Rauscher (2007), pointed out that intended public sector innovation and economic growth through a promoted flexibility of tax base presents a slim possibility, with negative impact being the greater likelihood.

In western economies, government performance assessment is done through public voting. China, now a transition economy, still exercises a highly centralized administration pattern within a hierarchical structure. With that, government performance assessment is conducted in a higher-to-lower pattern, i.e. performance at lower governments is assessed by their immediate higher governments instead of constituency voting. This performance appraisal mechanism leads unavoidably to the intense competition between local governments not so much in fiscal field as in the assessment standards set by their various higher-level governments. The higher-to-lower standards-pegged assessment mechanism provides not only more fiscal allocation but also better probability of administrative promotion to those officials who are higher on the league table.

There has recently arisen a tendency by domestic academia of researching the impact of this fashion of performance assessment on local government competition. Zhou Yean (2003) noted that the present assessment system has intensified the resources-grabbing competition between local government officials for the purpose of political benefits. Zhou Li'an (2004) also pointed out that this kind of political incentives will channel government-directed overinvestment into some sectors or projects and cause cutthroat competition. Another scholar, Dr. Qiu Xiaoming (2007), conducted a research, along an alternative line, on the formative mechanism of game competition between FDI investors under the foregoing performance assessment framework. Qiu's findings are highly indicative of the impact of the framework on the efficient utilization of foreign investment and the general economic performance.

These literature results lead the authors to the following two conclusions: (1) game-theory research on competition between domestic local governments for new-energy industries is the legacy of the 2008 global financial tsunami, thus greatly hampered by the paucity of advanced research data; (2) compared with the fiscal decentralization hypothesis, the present indicators-pegged (standards-pegged) mechanism is more realistic for China in terms of local government competition in developing new energy industries.

\section{GAME ANALYSIS ON GOVERNMENT COMPETITION}

The surging new-energy industries have, in general, assumed the visage of the pillar industry for governments at various levels by reason of its strong pulling force in boosting GDP and stretching upstream and downstream industries as well as its environmental friendliness. Let's assume that the administrative promotion of local officials are totally determined by GDP performance which, in turn, is mainly dependent on investments in new energy industries, then local government competition will turn out to be a chicken game. This fighting can actually be expounded on a mathematical model.

In a scramble for the higher or even the top place on the league table as well as in pursuit of such personal desires as profit maximization, office promotion, and individual reputation, local officials will come to be behaviorally deformed. There will be increasingly stronger impulse for capital- and technology-intensive investments in the new energy industries under the GDP pressure. They will exert, naturally willingly and blindly, every effort to pay higher prices. The competition is strongly akin to crossing a singlelog bridge by two people in the opposite direction, leaving open only two options: marching on or backing off. If they adopt the marching-on strategy, both parties will be mutually suicidal; if one party chooses to back off, the marching-on party will gain the competed benefits, taking everything away from the backing-off party; if they decide on the backing-off option, both parties will lose the competed benefits. This situation can be depicted in the following game matrix.

\section{TABLE I. GAME MATRIX}

Local government 1

Marching-on backing-off

\begin{tabular}{|c|c|c|}
\hline Marching-on & $-3,-3$ & 2,0 \\
\hline $\begin{array}{l}\text { Local government } 2 \\
\qquad \text { backing-off }\end{array}$ & 0,2 & $0, \quad 0$ \\
\hline
\end{tabular}

In a chicken game, the Nash equilibrium solution is that if one party marches on, the optimal strategy for the other party is to back off. However, in local government competition, political promotion goes hand in hand with GDP growth league table which depends heavily on the new energy investments. Each local government embraces the marching-on ideology and hopes for the backing-off of other parties. In this win-loss fighting scenario, shortsightedness and excess investment are the two fateful fruits, which, of course, will be impeding instead of prompting the overall development of new energy industries. What's more, it will surely churn out a new round of overcapacity among various alternative-energy sectors. Take the new-energy vehicles sector for example. Over forty unit-vehicle corporations have announced their plans 
to manufacture wholly electric cars, with their total numbers overpassing Japan and the United States, but only a bunch of laggards are on the road to real commercialization of their efforts. This competing framework will result in the decremental benefits from new-energy industries, thus weakening rather than strengthening the sinews of the sector's long-term perspectives.

\section{LOCAL GOVERNMENTS AND NEW-ENERGY INVESTORS}

Chicken game also happens between local governments and new energy investors. Chang'an Automobile Group made a point of it. By pocketing various new projects in the new-energy industries, Chang'an Group staged strategic investment negotiations with five local governments successively and separately. Any successful conclusion of cooperation negotiations lies exclusively with the extent to which local governments share their economic harvests. A closer examination into the negotiations displays an auxiliary situation in which the investors, by designing a sealed price auction, set local governments against each other in their bidding for the investment influx. The following is a model analysis on the inter-governmental competition in the above-mentioned auction context. Suppose that there is one potent investor who, by means of landing his potential investments, is in the capacity of creating millions and millions of output for a certain administrative region. The investor puts forth his sealed tendering package in front of multiple local governments. For simplicity, let there are just two bidding governments at first.

In this two-party competition model, we have $i=1,2$. With the cost of preferential policies dismissed, the benefits for the local government $i$ is $W_{i}=q\left(a_{i}-q\right)$, where $a_{i}$ is a valuation (estimated price) by the local government of the investment and $q$ is the magnitude of the investor's input. The benefit function, whose maximum value will be $\frac{a_{i}^{2}}{4}$, is marginally diminishing.

Under the forementioned auction model, preferential policies constitute the only strategy for the local government simply because it can offer no better strategies for alluring foreign investments. These preferential policies make the cost $c$ for the local government $i$, which presents itself as $C_{i}=d_{i} q^{2}$.

Now we will add another two assumptions into the auction model: (1) the two bidding governments offer the same price and the victory has to be decided by tossing up a coin, affording each party a fifty-fifty chance; (2) the bidding prices (W1 and W2) by the two governments are independent of each other and both are in a standarddistribution pattern above the coordinate values of $\left[0, \frac{a^{2}}{4}\right]$, with both parties being aware of the probability distribution of each other's bidding price.

In order to express the above as a static Bayesian game, we need to find out the behavioral space of the two local governments. The behavior of government $i$ is its bidding quotation $C_{i}$, which is admittedly featured with nonnegativity. Theoretically speaking, the local government is in a position to offer any non-negative figure as its quotation, meaning a behavioral space of $\mathrm{Ci}=[0, \infty)$. Considering the fact that the bidder will not offer a high-side price, the behavioral space could also be $\left[0, \frac{a^{2}}{4}\right]$. Based on the above assumptive description, we reach the three possible quotation options by the local government $i$ in the so-called sealed price auction context.

$$
\begin{aligned}
& \text { If } C_{i} \succ C_{j}, E_{i}=W_{i}-C_{i}=q\left(a_{i}-q\right)-d_{i} q^{2} ; \\
& \text { if } C_{i}=C_{j}, E_{i}=\frac{W_{i}-C_{i}}{2}=\frac{q\left(a_{i}-q\right)-d_{i} q^{2}}{2} \text {; }
\end{aligned}
$$$$
\text { if } C_{i} \prec C_{j}, E_{i}=0 \text {;where when } i=1, j=2 \text { and }
$$
when $i=2, j=1$.

Among the three optional quotations, the first one shows the benefits for the local government $i$ who bids higher than the other local government. The second explains the fiftyfifty probability of tossing up a coin when the two bidding governments quote the same price, thus halving the benefits from the first option. The third one displays the zero benefit for the local government $i$ when it bids lower than the other party.

Suppose the dismissal of preferential policies and the fact that local government $i$ 's bidding price $\left(C_{i}\right)$ is an evaluation $\left(W_{i}\right)$ and confirms to the strictly incremental quasi-differentiable function, then $C_{i} \leq W_{i}$ is obviously understandable in that no bidder will offer a price higher than the value of the investment itself. Game is something symmetrical and the optimal strategy in a game constitutes the optimal response to each other, or $C=C^{*}(w)$. With the assumed $C$ and $W$, the expected benefits for the local government $i$ turn out to be $E_{i}=\left(W_{i}-C_{i}\right) P$, where $p$ is the probability of $C_{i}>C_{j}$.

When the quoting prices by the two local governments demonstrate an interval continuous distribution, there seems to be a zero probability of equal price offers. The reason for that is that the price offers by the local governments are strictly incremental in relation to the evaluation (the estimated value) of the subject matter competed. When local government $j$ 's strategy is $C_{j}=d_{j} W_{j}$, local government $i$ 's response $\left(C_{i}\right)$, under a random $W_{i}$, needs to satisfy the following: 


$$
\begin{aligned}
\max _{b_{i}} \mathrm{E}_{i} & =\max _{b_{i}}\left(\mathrm{~W}_{\mathrm{i}}-\mathrm{C}_{\mathrm{i}}\right) \mathrm{P}\left\{C_{i}>d_{j} W_{j}\right\} \\
& =\max _{b_{i}}\left(\mathrm{~W}_{\mathrm{i}}-\mathrm{C}_{\mathrm{i}}\right) \mathrm{P}\left\{\mathrm{W}_{j}<\frac{C_{i}}{d_{j}}\right\} \\
& =\max _{b_{i}}\left(\mathrm{~W}_{\mathrm{i}}-\mathrm{C}_{\mathrm{i}}\right) \frac{C_{i}}{d_{j}},
\end{aligned}
$$

where the first order condition is $C_{i}^{*}=\frac{W_{i}}{2}$.

This result, to be proved again soon in the case of $n$ bidders, shows that the optimal pricing strategy for the local government is to halve its estimated price of the subject matter. This strategy is strongly indicative of the dilemma facing the local government during the bidding session. Higher prices ensure more chances of successful bidding, but lower benefit margins; lower prices may mean more possibilities of losing the bidding along with the influx of investments.

By referring to the foregoing analysis, we know that the investor, when faced with a two-party bidding situation, can only pocket half the price the government has evaluated for the subject matter. However, it also means that with more bidding participants the difference between the bidding price and the estimated price will decrease. The following is an example of a sealed price auction where there are $n$ bidding parties.

Suppose there are $n$ local governments as bidders, with their respective $W_{i}$ (estimated price) independent of each other and showing a continuous distribution interval of $\left[0, \frac{a^{2}}{4}\right]$. Given the symmetrical properties, i.e., $C_{j}=C^{*}\left(W_{j}\right)$, then we have:

$$
\begin{aligned}
\mathrm{P}\left\{C_{j}<C\right\} & =\mathrm{P}\left\{C^{*}\left(W_{j}\right)<C\right\} \\
& =\mathrm{P}\left\{W_{j}<C^{*-1}(C) \equiv \Phi(C)\right\} \\
& =\Phi(C),
\end{aligned}
$$

where $\Phi(C)=C^{*-1}(c)$ is the inverse function of $C^{*}$, or, to put it another way, the local government's estimated price will be $\Phi(C)$ when it opts $C$. If government $i$ is willing to accept $C$, its payment function for the bidding game will be:

$$
E_{i}=(\mathrm{W}-\mathrm{C}) \prod_{j \neq i} P\left(C_{j}<C\right)=(\mathrm{W}-\mathrm{C}) \Phi^{n-1}(C)
$$

with the optimal first order condition being:

$$
-\Phi^{n-1}(C)+(\mathrm{W}-\mathrm{C})(n-1) \Phi^{n-2} \Phi^{\prime}(C)=0 .
$$

Under the equilibrium condition, i.e., $\Phi(C)=W$, the first order condition can be rewritten as:

$$
\begin{aligned}
& -\Phi(C)+(\Phi(C)-C)(n-1) \Phi^{\prime}(C)=0 \\
& (n-1) \Phi d \Phi=\Phi d c+(n-1) c d \Phi
\end{aligned}
$$

When both sides of the immediate above equation are multiplied by $\Phi^{n-2}$, we have a new equation as follows:

$$
\begin{aligned}
& (n-1) \Phi^{n-1} d \Phi=\Phi^{n-1} d c+(n-1) c \Phi^{n-2} d \Phi \\
& \frac{n-1}{n} d \Phi^{n}=d c \Phi^{n-1}
\end{aligned}
$$

Solving the new equation, we have the result:

$$
C^{*}(W)=\frac{(n-1) W}{n} \text {. }
$$

The above result shows that $C^{*}$ will get increasingly closer to the estimated price $W$ by the bidding local government, and, in particular, when $n \rightarrow \infty$, we will see $C^{*} \rightarrow W$. In accordance with the above resulting equation, we are with the conclusion that with more and more local governments bidding for the investment, investors will gain higher and higher profit margins. Also it means that investors are in a better position than the local governments in the chicken game on account of the intense competition between local governments themselves.

\section{CONCLUSION}

Under the present performance assessment mechanism for local governments, the competition for new energy industries is obviously turned into a chicken game. Not only is this game detrimental to the overall improvement of the industries in question, it will develop another round of overcapacity in the new energy sector as well. In addition, the option will lead to decreasing benefits for whole administrative regions and eventually harm the long-term growth of the industries concerned.

To avoid the present messy competition situation, we need to discard the existing performance assessment mechanism for the local governments and strive for new appraisal indicators, stressing instead, for example, public satisfaction and civil society construction. Accordingly, local governments should shift their attention from singlytargeted economic growth to resources efficiency and economic equality by providing, for instance, more public services.

\section{REFERENCES}

[1] David scones. "Common and Private Values of the Firm in Tax Competition" [J]. Journal of Public Economic Theory, 2001, 3(4): 373-389.

[2] Kangoh lee. "Factor Ownership and Governmental Strategy Interaction" [J]. Journal of Public Economic Theory, 2003, 5(2): 345361.

[3] Michael Rauscher. "Tax Competition, Capital Mobility and Innovation in the Public Sector" [M]. Vermiform Social Political and Blackwell Publishing Ltd, 2007.

[4] Sergio. "Inter-Jurisdictional Fiscal Competition: A Review of the Literature and Policy Recommendations" [J]. Journal of Political Economy, 2005, 25(3): 295-313 
[5] Qiu Xiaoming. "FDI and Local Government Incentives" [J]. Productivity Research, 2007(1):52-55.

[6] Zhou Yean. "Local Government Competition and Economic Growth" [J]. Journal of China Renmin University, 2003(1):25-31.

[7] Zhou Li'an. "Incentives and Cooperation in Administrative Promotion Games"[J] . Economics Research, 2004(6): 47-55.

[8] Zhang Weiying. "Game Theory and Information Economics" [M].Beijing: Joint Publishing Company,1996.

[9] Yang Jun. "Latent Dangers in Local Governments' New-Energy Programs" [J] . Southern Window, 2009(09): 15-17. 